\title{
Effects of biochar on nutrients and the microbial community structure of tobacco-planting soils
}

\author{
Gao, Lin ${ }^{1}$, Wang, Rui ${ }^{2}$, Shen, Guoming ${ }^{1}$, Zhang, Jixu ${ }^{1}$, Meng, Guixing ${ }^{2}$, Zhang, Jiguang ${ }^{1 *}$ \\ ${ }^{1}$ Tobacco Research Institute of Chinese Academy of Agricultural Sciences, Qingdao 266101, China. ${ }^{2}$ Enshi \\ Tobacco Company of Hubei Province, Enshi 445000, China. *Corresponding author: zhangjiguang@caas.cn
}

\begin{abstract}
The effect of rice straw biochar on soil nutrients was studied using a randomized block experimental design in a tobacco-planting field, and differences in soil bacterial and fungal community structures were studied using high-throughput sequencing technology. The results indicated that the soil $\mathrm{pH}, \mathrm{CEC}$, total organic carbon (TOC), inorganic carbon (IC), soil total nitrogen (total N), total potassium (total K), available phosphorus (available $\mathrm{P}$ ), and available potassium (available $\mathrm{K}$ ) contents were all increased with the biochar application. TOC and available $\mathrm{P}$ contents increased by $38.19 \%$ and $22.38 \%$, respectively, in the T2 treatment (4500 kg.ha- ${ }^{-1}$ biochar) compared to those in control (CK). But the soil dissolved organic carbon ( DOC) and available nitrogen (available N) content decreased by $13.07 \%$ and $9.89 \%$ in T2 treatments compared to the CK, respectively. Soil bacteria composition mainly consisted of Proteobacteria, Actinobacteria, and Acidobacteria, and the Proteobacteria proportion represented $>50 \%$ of the bacterial community. The Actinobacteria proportion decreased, but Proteobacteria and Acidobacteria proportions increased with increasing biochar amounts. Fungi in tobaccoplanting soils were mainly Ascomycota (>75\%), but this proportion decreased as the biochar amount increased. However, Zygomycota and Basidiomycota proportions increased with increasing biochar amounts. Therefore, biochar application could improve the soil nutrient status and affect microbial community structure. Rice straw biochar application promoted fungal community diversity in tobacco-planting soils.
\end{abstract}

Keywords: Biochar, tobacco-planting soil, soil nutrients, microbial community structure 


\section{Introduction}

Flue-cured tobacco (Nicotiana tabacum Linn.) is one of the most important economic crops in China, and the cultivated area and tobacco leaf yield rank first in the world (Zhu, 2008). Because of the longterm continuous cropping and over use of chemical fertilizers, the soil environment used for tobacco planting gradually deteriorates, and the quality of tobacco leaves decreases (Zhang et al., 2016; Shi et al., 2009). Good soil conditions are required to produce high quality tobacco leaves. Therefore, it is very important to study and utilize soil amendments in tobacco-planting areas with serious soil degradation. Biochar is a solid material obtained from the thermochemical conversion of biomass in an oxygen-limited environment. Biochar is constitutionally stable, rich in nutrients, and it can persist in soil for thousands of years (Ouyang et al., 2013; Amin et al., 2016). Furthermore, biochar is recognized as a good soil amendment, because it provides a number of soil health benefits. For instance, biochar can reduce nutrient loss, provide greater nutrient availability in soil, and improve the efficiency of nutrient utilization in crops (Curaqueo et al., 2012; Widowati and Asnah, 2014 ). Biochar has a large specific surface area, porous microstructure, and abundant surface functional groups, which can provide favorable soil conditions for microbes (Farrell et al., 2013; Milla et al., 2013). Moreover, the amount and structural diversity of soil microbes can change after the application of biochar (Khodadad et al., 2011).

In China, various types of straw resources are abundant, and the country produces $0.6-0.7$ billion tons of straw each year, accounting for $30 \%$ of global annual production (Zeng et al., 2007). However, most straw resources are directly burned in the field, abandoned at the edge of the field, or combusted as cooking and heating fuels that produce serious air pollution and resource waste. However, turning straw into biochar under low temperatures and limited oxygen conditions is a promising approach for the utilization of waste resources. In recent years, straw biochar has been applied in agricultural fields as a soil conditioner, which has attracted substantial attention. It was reported that more than $50 \%$ of rice straw are directly burned in the field, abandoned, or combusted as cooking and heating fuel in China (Zeng et al., 2007), which is a great waste of straw resources. Long-term trials showed that part of crop straw can be removed without depleting soil carbon under paddy or irrigated conditions (Tarkalson et al., 2009). And meanwhile, all tobacco straws are removed from the field for soil-borne disease control, which always lose the soil carbon. So rice straw or its biochar incorporation into tobacco field may be a selective method to improve soil fertility and soil ecosystem health (Zhang et al., 2016).

The application of rice straw biochar to tobaccoplanting soils is currently at the initial stage. And the effects of biochar on tobacco-planting soils and associated micro-ecological mechanisms have not been studied deeply. Therefore, this study was conducted to determine the effects of straw biochar on soil nutrients and microbial community structure in tobacco-planting soils, and the results could provide theoretical and practical guidance for the application of biochar in tobacco fields in Southern China.

\section{Materials and Methods}

\subsection{Materials}

The experiment was conducted at the "Qing Jiang Yuan" Modern Tobacco Agriculture Science and Technology Park in Enshi, Hubei Province in 2014. 
The tested flue-cured tobacco variety was Yunyan 87 , and the soil type was yellow-brown soil with the following properties: $\mathrm{pH} 6.88,23.98{\mathrm{~g} \cdot \mathrm{kg}^{-1}}^{-1}$ organic matter, $147.87 \mathrm{mgkg}^{-1}$ alkali-hydrolyzable nitrogen, $34.70 \mathrm{mg} \mathrm{kg}^{-1}$ available phosphorus, and 188.81 $\mathrm{mg} \mathrm{kg}^{-1}$ available potassium.

The tested biochar was derived from rice straw at $550{ }^{\circ} \mathrm{C}$ for $8 \mathrm{~h}$, and it was manufactured by the Institute of Soil Science, Chinese Academy of Sciences. Its properties were as follows: $\mathrm{pH} 9.20,630 \mathrm{~g} \mathrm{~kg}^{-1}$ total carbon content, $13.5 \mathrm{~g} \mathrm{~kg}^{-1}$ total nitrogen content, $4.50 \mathrm{~g} \mathrm{~kg}^{-1}$ total phosphorus and $21.5 \mathrm{~g} \mathrm{~kg}^{-1}$ total potassium (Zhang et al., 2016). Biochar is rich in carboxyl groups and has more micro-pores. And the pore sizes of the tested biochar are mainly below 5 um. The FTIR spectra indicate that the typical wide absorption peaks at $3500-3200 \mathrm{~cm}^{-1}, 1700-1600 \mathrm{~cm}^{-1}$ and $1200-1000 \mathrm{~cm}^{-1}$ are attributed to $-\mathrm{OH}$ stretching, $\mathrm{C}=\mathrm{C}$ stretching and $\mathrm{C}-\mathrm{O}$ stretching individually of the tested biochar.

\subsection{Experimental design}

The field experiment included three treatments (CK, T1 and $\mathrm{T} 2$ ) with three replicates. $\mathrm{CK}$ was the un-amended treatment; T1 was the $2250 \mathrm{kgha}^{-1}$ biochar amended treatment and 2 was the $4500 \mathrm{kgha}^{-1}$ biochar amended treatment. Each trial plot covered an area of $100.8 \mathrm{~m}^{2}$ $(3.6 \mathrm{~m} \times 28 \mathrm{~m})$, and all nine plots $(3 \times 3)$ were arranged in a randomized complete block design.

Biochar was ground and sieved through a $2 \mathrm{~mm}$ mesh, then it was uniformly spread on the surface of the tobacco-planting soil, and was incorporated into the soil $(0-20 \mathrm{~cm}$ depth) using a micro-diesel plow 20 days prior to the transplantation of fluecured tobacco. Tobacco production was managed following the local conventional practice, with the exception of biochar use, and it was consistent across all treatments.

\subsection{Sampling and analysis}

The soil samples were collected on September 10 (120 $\mathrm{d}$ after transplanting) in 2015, when tobacco plants were at mature stage. Each soil sample was taken from the surface layer $(0-20 \mathrm{~cm})$ in each plot (i.e., replicates) by five-spot-sampling method. The composite soil samples were immediately transported to the laboratory in plastic bags through portable refrigerator. Plant residues and other organic debris were carefully removed using forceps. One part of the samples were air-dried and stored at room temperature for soil chemical analysis, and another part was kept moist and stored at $-40{ }^{\circ} \mathrm{C}$ on more than one month for the measurement of microbial community structure.

\subsection{Chemical properties of soil samples}

Soil $\mathrm{pH}$ in distilled water $(1: 2.5 \mathrm{w} / \mathrm{v})$ was measured using a $\mathrm{pH}$ meter equipped with a glass electrode. The cation exchange capacity (CEC) of soil was determined with an ammonium acetate method (Dohrmann, 2006). Total soil organic carbon (TOC) and inorganic carbon(IC) were determined using a Shimadzu Solid Sample Module (SSM-5000A) combined with a TOC analyzer. Soil dissolved organic carbon (DOC) was determined with a TOC-VE (Shimadzu, Japan) . Total $\mathrm{N}$ was determined by Kjeldahl digestion-distillation method. Total $\mathrm{P}$ was extracted using melt sodium hydroxide and measured using the molybdenum stibium anticolor method. Total $\mathrm{K}$ was extracted using melt sodium hydroxide and then measured by flame emission spectrometry. Available N (Alkali-hydrolyzable N) was determined by alkali solution method, and available P (Olsen-P) was determined using the molybdenum blue colorimetric method after extraction with sodium bicarbonate. Available K (Extractable $\mathrm{K})$ was determined using ammonium acetate extraction and the flame photometric method. And all 
these above methods were detailed in the reference (Sparks et al., 1996).

\subsection{Extraction of genomic DNA}

The total genomic DNA of soil samples was extracted by following the instructions of the Mo Bio microbial DNA extraction kit (Power Soil TM DNA Isolation Kit, Mo Bio, USA). The integrity of the DNA was determined by $1 \%$ agarose gel electrophoresis, while the purity and concentration of the DNA were assessed using a Nanodrop microvolume spectrophotometer (Thermo Fisher Scientific).

\subsection{Amplicon generation}

The following primers were used to generate amplicons: 16S V4: 515F-806R, 18S V4: 528F-706R. 16S /18S rRNA genes were amplified used specific primer with the required barcodes. All PCR reactions were conducted in $30 \mu \mathrm{L}$ reactions with $15 \mu \mathrm{L}$ of Phusion ${ }^{\circledR}$ High-Fidelity PCR Master Mix (New England Biolabs); $0.2 \mu \mathrm{M}$ of forward and reverse primers, and approximately $10 \mathrm{ng}$ of template DNA. Thermal cycling conditions were as follows: initial denaturation at $98^{\circ}$ $\mathrm{C}$ for $1 \mathrm{~min} ; 30$ cycles of denaturation at $98^{\circ} \mathrm{C}$ for 10 s, annealing at $50{ }^{\circ} \mathrm{C}$ for $30 \mathrm{~s}$, and elongation at $72{ }^{\circ} \mathrm{C}$ for $60 \mathrm{~s}$; and $72^{\circ} \mathrm{C}$ for $5 \mathrm{~min}$.

\subsection{PCR product quantification and qualification}

The same volume of $1 \mathrm{X}$ loading buffer (containing SYB green) was mixed with the PCR products, and electrophoresis was conducted on a $2 \%$ agarose gel for detection. Samples exhibiting a bright main strip between $400-450 \mathrm{bp}$ were selected for further experiments.

\subsection{PCR product mixing and purification}

PCR products were mixed in equidensity ratios, and PCR product mixtures were then purified using a GeneJET Gel Extraction Kit (Thermo Scientific).

\subsection{Library preparation and sequencing}

Sequencing libraries were generated using an NEB Next ${ }^{\circledR}$ Ultra $^{\mathrm{TM}}$ DNA Library Prep Kit for Illumina (NEB, USA) following manufacturer's recommendations, and index codes were added. Library quality was assessed usinga Qubit 2.0 Fluorometer (Thermo Scientific) and an Agilent Bioanalyzer 2100 system. Libraries were then sequenced on an Illumina MiSeq platform, and 250-300 bp paired-end reads were generated.

\section{Results}

\subsection{Analysis of soil nutrients}

With the increase in the amount of biochar application, the soil $\mathrm{pH}, \mathrm{CEC}, \mathrm{TOC}$, IC, soil total N, total K, available $\mathrm{P}$, and available $\mathrm{K}$ contents showed an increasing trend in the tobacco-planting soil (Table 1). Meanwhile, TOC and available K contents increased by $38.19 \%$ and $22.38 \%$, respectively, in the $\mathrm{T} 2$ treatment compared to the $\mathrm{CK}$, whereas the soil DOC and available $\mathrm{N}$ content decreased as the biochar amount increased, and they decreased by $13.07 \%$ and $9.89 \%$ in $\mathrm{T} 2$ treatments compared to the CK, respectively. Furthermore, the soil total P content only fluctuated slightly with the increase of biochar application among all the treatments. 
Table 1. Soil chemical properties of different biochar treatments.

\begin{tabular}{|c|c|c|c|c|c|c|c|c|c|c|c|}
\hline Treatments & $\mathrm{pH}$ & $\mathrm{CEC}$ & $\begin{array}{c}\text { TOC } \\
\left(\mathrm{g} \cdot \mathrm{kg}^{-1}\right)\end{array}$ & $\begin{array}{c}\text { DOC } \\
\left(\mathrm{mg} \cdot \mathrm{kg}^{-}\right. \\
1)\end{array}$ & $\begin{array}{c}\mathrm{IC} \\
\left(\mathrm{g} \cdot \mathrm{kg}^{-1}\right)\end{array}$ & $\begin{array}{c}\text { Total N } \\
(\%)\end{array}$ & $\begin{array}{c}\text { Total P } \\
(\%)\end{array}$ & $\begin{array}{c}\text { Total K } \\
(\%)\end{array}$ & $\begin{array}{c}\text { Available N } \\
\left(\mathrm{mg} \cdot \mathrm{kg}^{-1}\right)\end{array}$ & $\begin{array}{c}\text { Available P } \\
\left(\mathrm{mg} \cdot \mathrm{kg}^{-1}\right)\end{array}$ & $\begin{array}{c}\text { Available K } \\
\left(\mathrm{mg} \cdot \mathrm{kg}^{-1}\right)\end{array}$ \\
\hline CK & $7.09 \mathrm{~b}$ & $6.63 b$ & $13.93 \mathrm{c}$ & $158.20 \mathrm{a}$ & $10.22 b$ & $0.150 \mathrm{~b}$ & $0.109 \mathrm{a}$ & $1.547 \mathrm{c}$ & $112.00 \mathrm{a}$ & $93.65 \mathrm{c}$ & $272.23 b$ \\
\hline $\mathrm{T} 1$ & $7.12 \mathrm{ab}$ & $7.25 \mathrm{a}$ & $16.66 \mathrm{~b}$ & $150.41 \mathrm{a}$ & $12.31 \mathrm{ab}$ & $0.163 \mathrm{ab}$ & $0.097 \mathrm{a}$ & $1.752 \mathrm{~b}$ & $100.33 b$ & $101.97 \mathrm{~b}$ & $326.86 a$ \\
\hline $\mathrm{T} 2$ & $7.17 \mathrm{a}$ & $7.50 \mathrm{a}$ & $19.25 \mathrm{a}$ & $148.52 \mathrm{a}$ & $15.45 \mathrm{a}$ & $0.175 \mathrm{a}$ & $0.112 \mathrm{a}$ & $1.921 \mathrm{a}$ & $100.92 b$ & $112.15 \mathrm{a}$ & $333.15 \mathrm{a}$ \\
\hline
\end{tabular}

Different small letters in the same column represent significant difference at $\mathrm{P}<0.05$.

\subsection{Operational taxonomic unit data analysis}

The number of soil bacteria sequences obtained from the T2 treatment was greater than that of the other treatments, following filtering and chimera removal. The highest number of operational taxonomic units (OTUs) associated with bacterial species was found in the $\mathrm{CK}$ treatment (Figure 1). However, the number of fungal sequences in the $\mathrm{CK}$ treatment was higher than that of the other treatments, following filtering and chimera removal (Figure 1). The highest number of OTUs associated with fungal species was found in the $\mathrm{T} 1$ treatment.
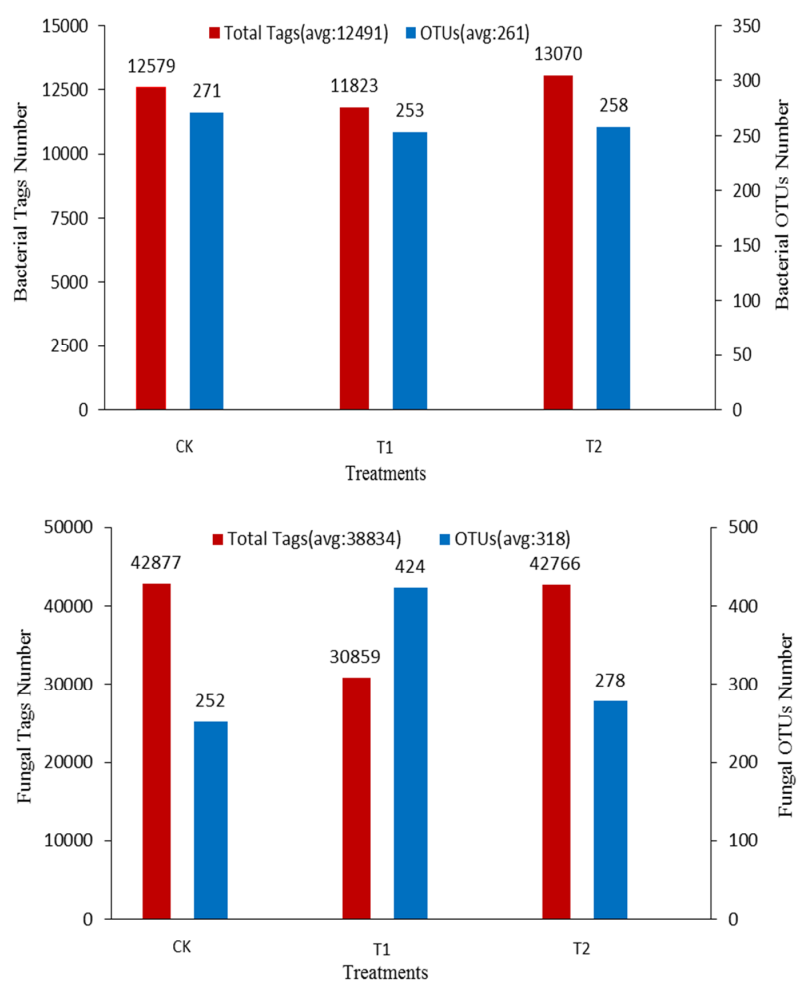

Figure 1. Analysis of tags and OTUs of bacterial and fungal communities. 


\subsection{Species abundance analysis}

The community structure of soil bacteria and fungi (at the phylum level) varied after the biochar application. Regarding soil bacteria, the average proportion of Proteobacteria was the highest (>50\%). The Proteobacteria, Actinobacteria, and Acidobacteria were thepredominant bacteria in the obacco-planting soils. As the amount of applied increased, the proportion of Actinobacteria decreased, but the Proteobacteria and Acidobacteria proportions increased (Figure 2). Regarding soil fungi, the average Ascomycota proportion $(>75 \%)$ in tobacco-planting soils was the highest (Figure 3). The Ascomycota proportion exhibited a decreasing trend as the amount of biochar applied increased, but the Zygomycota and Basidiomycota proportions increased.

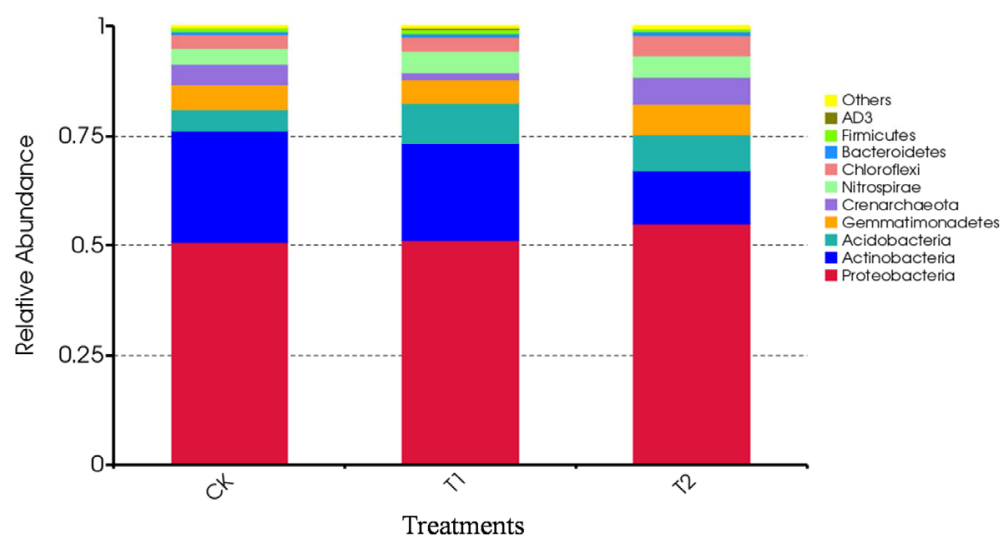

Figure 2. Relative abundance of soil bacterial communities at the phylum level.

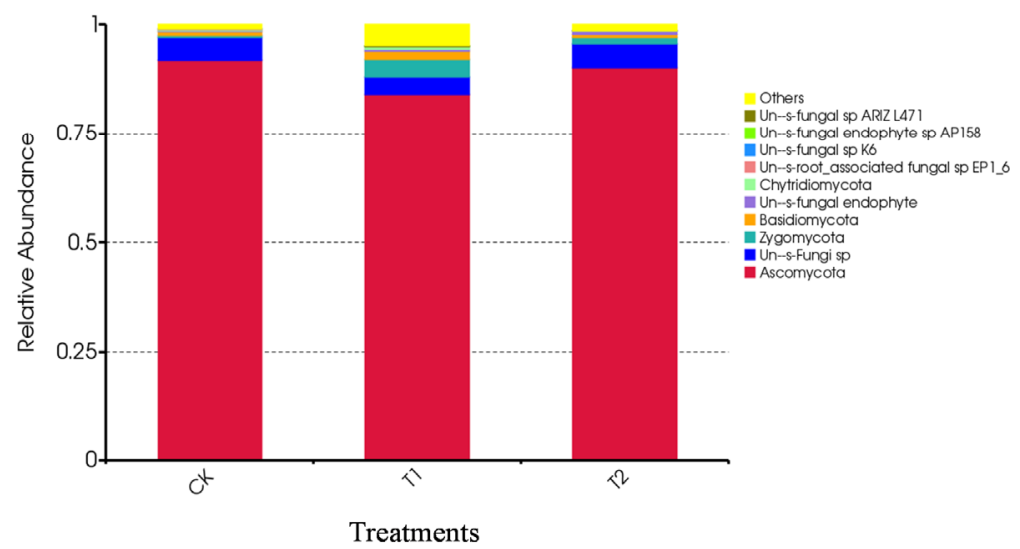

Figure 3. Relative abundance of soil fungi communities at the phylum level. 


\subsection{Species diversity analysis}

The Chaol and Shannon indices of soil bacteria and fungi differed after the biochar application (Figure 4 and Figure 5). The Chao1 and Shannon indices of soil bacteria were highest in the CK and $\mathrm{T} 2$ treatments, respectively. However, the Chaol and Shannon indices of soil bacteria varied little among the treatments.
The Chaol and Shannon indices of soil fungi were highest in the T1 treatment, and both indices were lowest in the $\mathrm{CK}$ treatment. However, greater differences were detected between the Chao1 and Shannon indices of soil fungi among the treatments. Therefore, biochar application had little effect on the diversity of the soil bacterial community, but it greatly influenced the diversity of the soil fungal community present in the tobacco field.
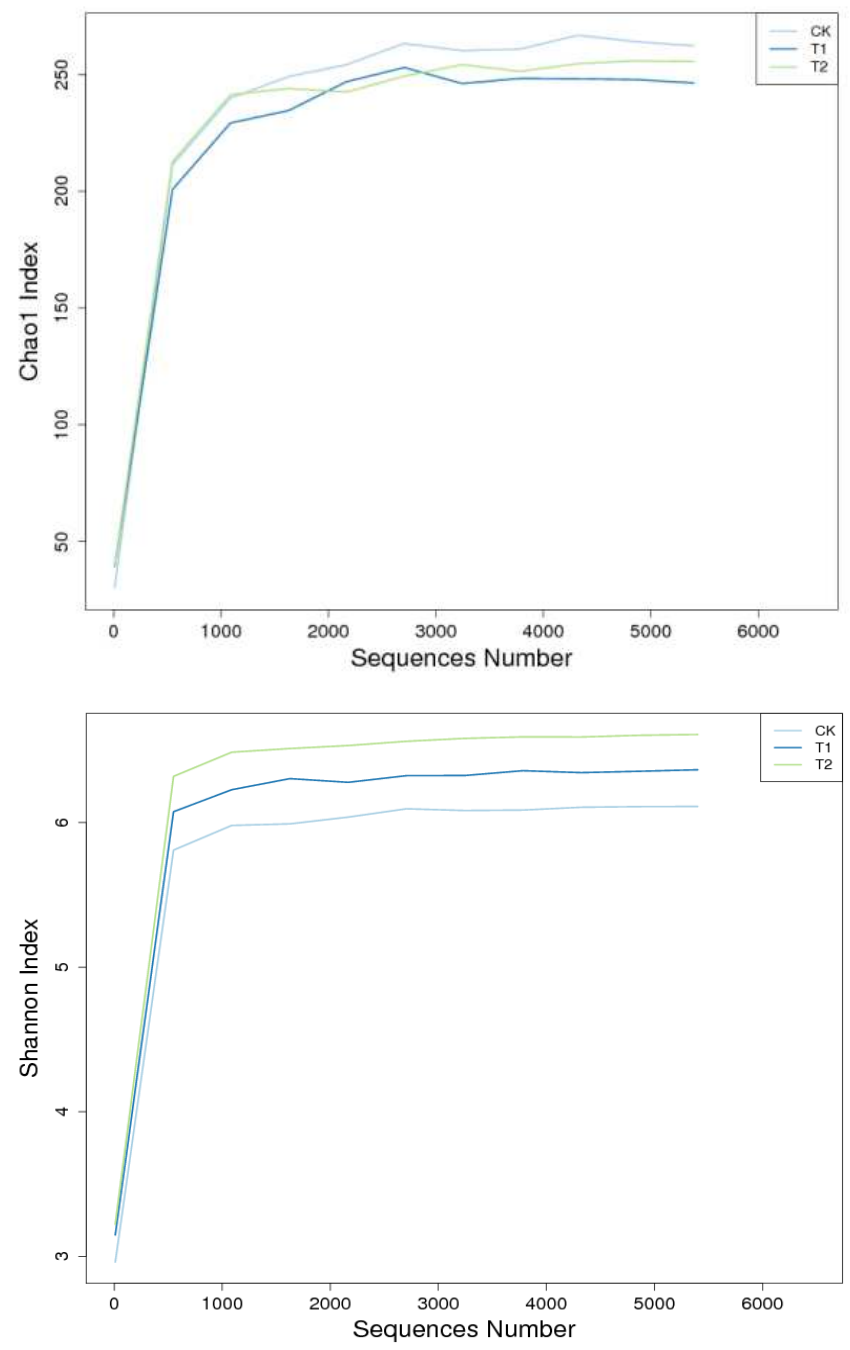

Figure 4. Chaol and Shannon indices of soil bacteria from different treatments. 

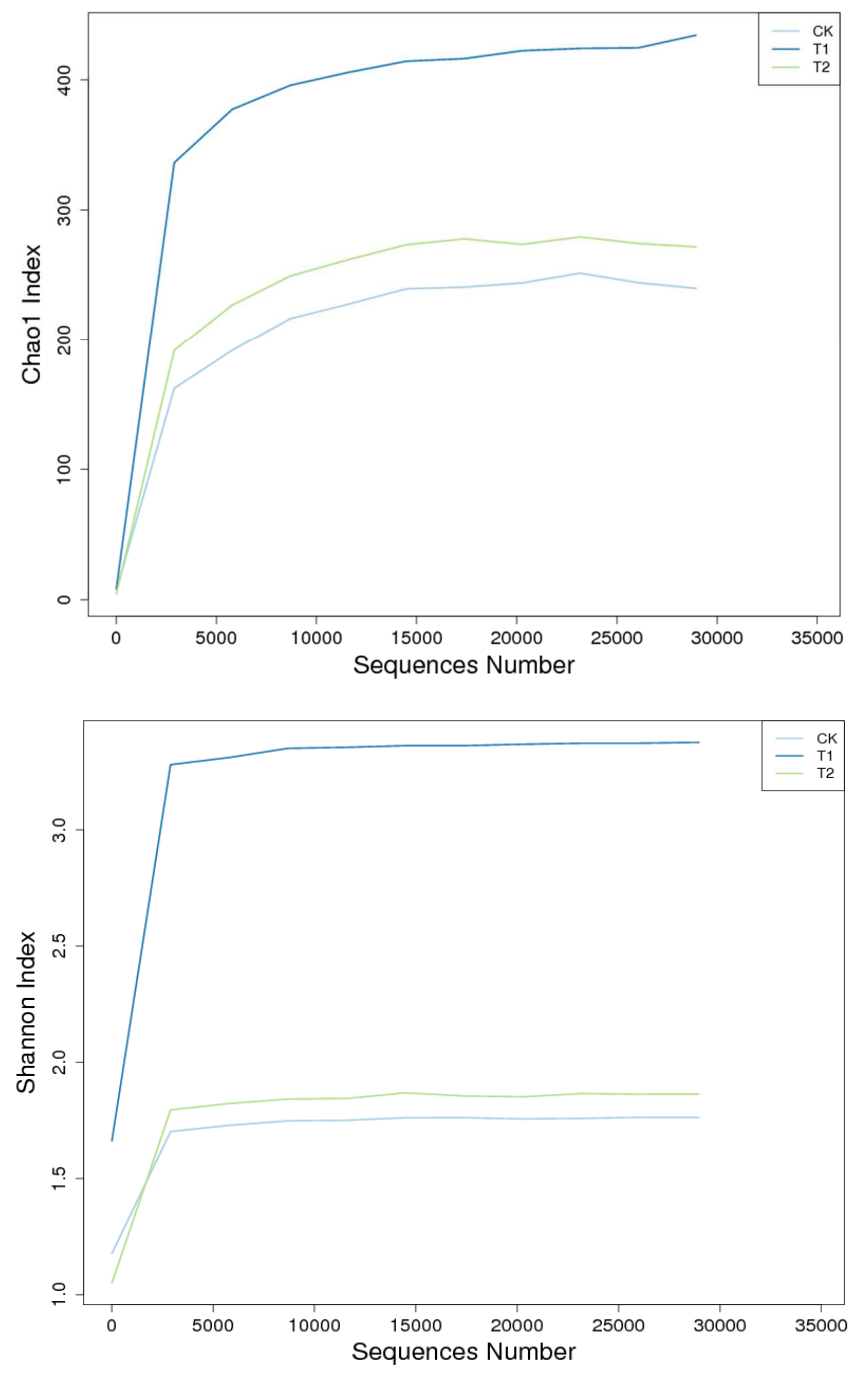

Figure 5. Chao1 and Shannon indices of soil fungi from different treatments.

\subsection{Cluster analysis}

The bacteria communities associated with different treatments were divided into two clusters based on the unweighted UniFrac method (Figure 6). T1 and $\mathrm{T} 2$ treatments were placed into one class, and the $\mathrm{CK}$ treatment was placed in the other. The dominant soil bacteria in all treatments (at the phylum level) were mainly Proteobacteria, Actinobacteria, Acidobacteria, and Gemmatimonadetes. The soil fungi communities associated with the treatments were divided into two clusters based on Bray Curtis dissimilarity metric, and the dominant soil fungi (at the phylum level) were $A s$ comycota, Zygomycota, and Basidiomycota (Figure 7). 


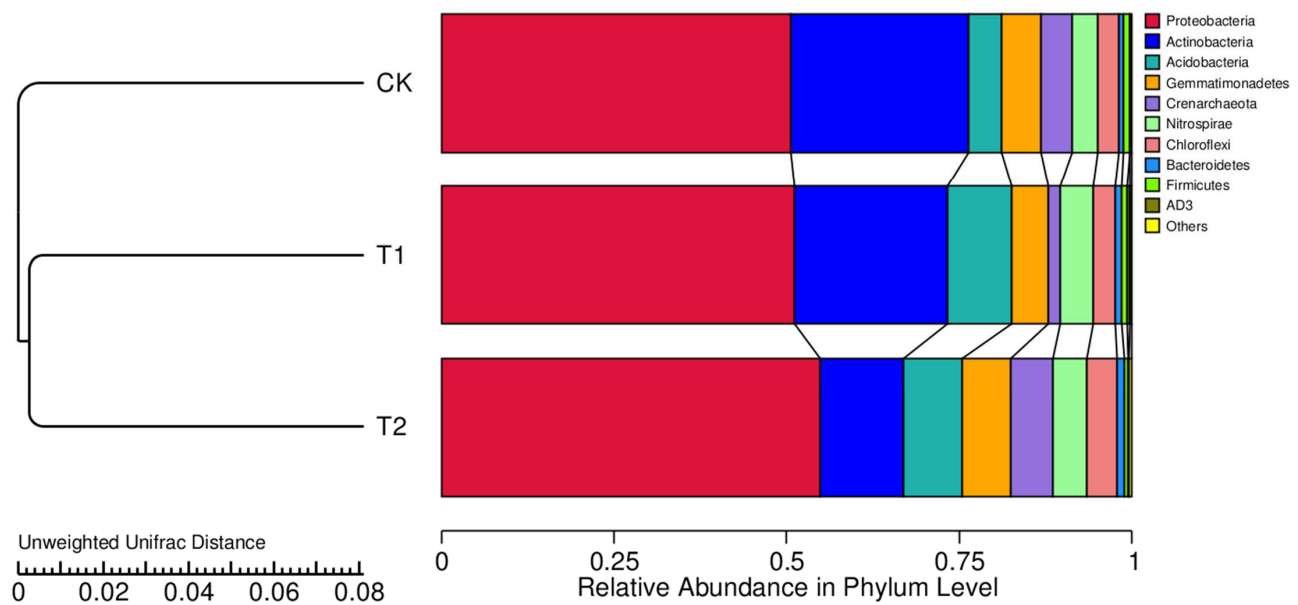

Figure 6. Clustering diagram of soil bacteria (at the phylum level)from different treatments.

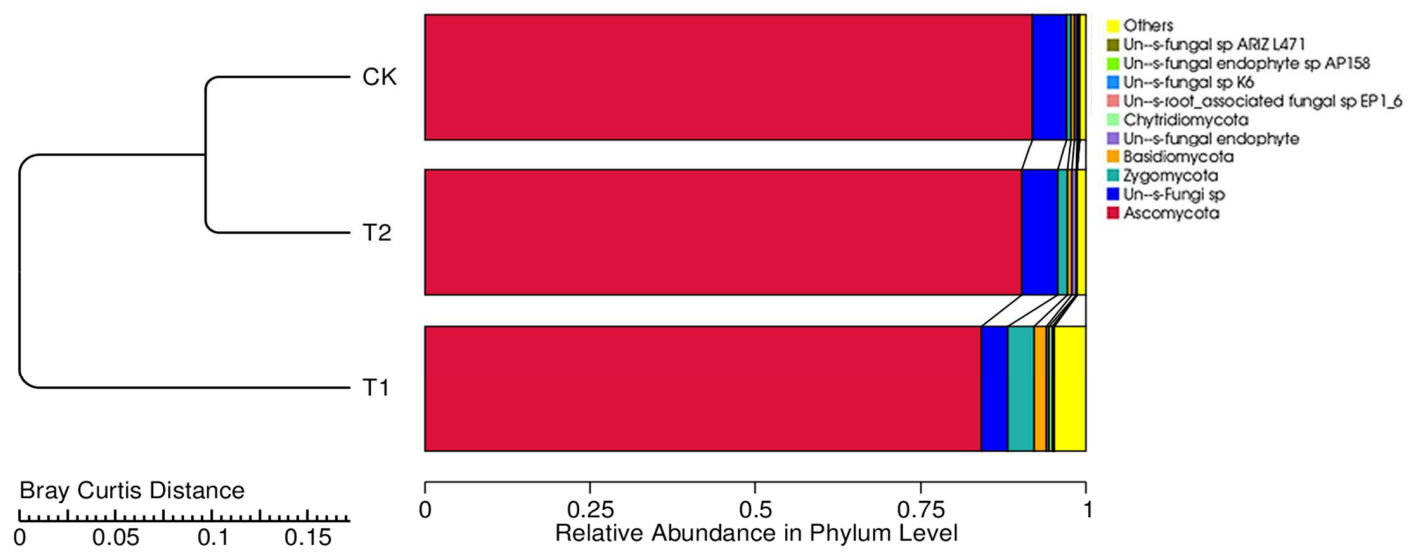

Figure 7. Clustering diagram of soil fungi (at the phylum level) from different treatments. 


\section{Discussion}

Biochar is rich in mineral nutrient content, and it has a distinct physical structure, which can improve soil nutrient absorption and availability and promote crop growth (Ahmed et al., 2016). The soil available P, available K, TOC and IC contents exhibited an increasing trend as the applied biochar amount increased in this study, which was consistent with the results of other studies (Ahmed et al., 2016). The biochar application could increase the available $\mathrm{K}$ content for its higher potassium content and bioavailability in red soil and yellow brown soil (Syuhada et al., 2016). The total K and available $\mathrm{K}$ contents in this study also had the similar trend after biochar application. Biochar could decrease the potassium leaching, and meanwhile promote the release of adsorbed soil potassium in the tobacco field (Abujabhah et al., 2016; Pandian et al., 2016). And there is no consistent conclusion about the effect of biochar on soil available $\mathrm{P}$, though biochar contains a large amount of phosphorus with high effectiveness (Enders et al., 2012; Shen et al., 2016). However, phosphorus adsorption and desorption in soil can also be influenced by the biochar additions and soil types. The available $\mathrm{P}$ content in alkaline soil decreased after the biochar application because of the large amount of calcium and magnesium cations in alkaline soil (Chintala et al., 2014). The available P content in the yellowbrown tobacco soil exhibited an increasing trend after biochar application, but the mechanism requires further study. Nitrogen is the most important nutrient affecting the yield and quality of tobacco. Biochar can affect the retention and cycling of nitrogen, and can improve its efficiency in soils (Spokas et al., 2012; Chu et al., 2014). In this experiment, the soil DOC and available $\mathrm{N}$ content both exhibited a declining trend associated with biochar application at the tobacco mature stage, which may be related to the adsorption and fixation of DOC and content of exchangeable nitrogen (ammonia and nitrate) in soil by biochar application ( Zhang et al., 2012; Dempster et al., 2012).

Soil microorganisms are the most active components in the soil carbon pool, which is sensitive to environmental changes. The porous nature and adsorption properties of biochar provide a favorable environment for the growth and reproduction of soil microorganisms (Warnock et al., 2010).The soil nutrient cycle and the nutrient supply were altered following the biochar application, and this in turn affected the composition and structure of the soil microbial communities (Farrell et al., 2013). Species diversity and abundance of soil microorganisms after biochar application differed from those of untreated soils (Grossman et al., 2010). For instance, the abundance of the microbial population (Bacillus spp., Filamentous fungi, Pseudomonas spp.) in pepper-planting soils increased significantly following biochar applications (Graber et al., 2010). Furthermore, biochar applications increased the Shannon index of soil microbial communities in a continuous cropping cotton field (Gu et al., 2014). The diversity of soil bacterial increased by $25 \%$ following biochar application compared to untreated soils (Otsuka et al., 2008). In present study, the proportion of Actinobacteria decreased with increasing amounts of biochar, but the proportion of Proteobacteria and Acidobacteria increased. Therefore, biochar influenced the community structure of soil bacteria. On the other hand, soil fungi such as Zygomycota and Glomeromycota also increased after the biochar application, but the abundance of Basidiomycota and Ascomycota decreased (Jin, 2010). Our results indicated that the proportion of Ascomycota exhibited a downtrend as the biochar amount increased, but the proportion of Zygomycota and Basidiomycota showed the opposite trend. The effect of biochar on soil microbial community structure is very complex and variable, and the responses of different soil microbial communities varied after biochar application (Khodadad et al., 2011). 
Changes in the soil environment after biochar application were the main factors that affected the soil microbial community, thus leading to differences in the composition and structure of the microbial community (Gul et al., 2015). In most tobacco planting areas in China, tobacco-planting soil always differs from other farmland soils because of long term continuous cropping. Hence, the effect of biochar on the soil microbial community and mechanisms associated with tobacco-planting soil require further study.

\section{Conclusions}

The soil $\mathrm{pH}, \mathrm{CEC}, \mathrm{TOC}, \mathrm{IC}$, total $\mathrm{N}$, available $\mathrm{P}$, and available $\mathrm{K}$ contents all increased following the biochar application, but the soil DOC and available $\mathrm{N}$ content showed a decreasing trend at the maturity stage of flue-cured tobacco. Biochar application greatly affected the abundance and diversity of soil bacteria and fungi in the tobacco field. The proportion of Actinobacteria in the soil decreased as the biochar amount increased, but the proportion of Proteobacteria and Acidobacteria increased. The proportion of Ascomycota exhibited a downtrend, but the proportion of Zygomycota and Basidiomycota increased as the biochar amount increased. Biochar application had little effect on soil bacteria community diversity, but it greatly influenced soil fungi community diversity in the tobacco field. Therefore, rice straw biochar has a positive effect on soil nutrients and the microbial community structure in tobacco fields, and the used of rice straw biochar as an amendment to improve soil fertility and microbial environment has favorable application prospects in the tobacco fields of China.

\section{Acknowledgements}

This work was financially supported by the National Natural Science Foundation of China (41201291), the Agricultural Science \& Technology Innovation Program (ASTIP-TRIC06, TRIC05) and the Basic Research Fund of Chinese Academy of Agricultural Sciences (TRIC2016). We thank the anonymous reviewers and the editor for their valuable comments and suggestions, which distinctly contributed to the improvement of this paper.

\section{References}

Abujabhah, I.S., Doyle, R., Bound, S.A., Bowman, J.P. 2016. The effect of biochar loading rates on soil fertility, soil biomass, potential nitrification, and soil community metabolic profiles in three different soils. Journal of Soils and Sediments. 9, 2211-2222.

Ahmed, A., Kurian, J., Raghavan, V. 2016. Biochar influences on agricultural soils, crop production, and the environment: A review. Environmental Reviews. 4, 495-502.

Amin, F.R., Huang, Y., He, Y.F., Zhang, R.H., Liu, G.Q., Chen, C. 2016. Biochar applications and modern techniques for characterization. Clean Technologies and Environmental Policy. 5, 1-17.

Chintala, R., Schumacher, T.E., Mcdonald, L.M., Clay, D.E., Malo, D.D., Papiernik, S.K., Clay, S.A., Julson, J.L. 2014. Phosphorus sorption and availability from biochars and soil/biochar mixtures. Clean-Soil, Air, Water. 5, 626-634.

Chu, J., Xue, J.H., Jin, M.J., Wu, Y.B. 2014. Review of researches on effects of biochar in reducing nitrogen and phosphorus losses with agricultural nonpoint source pollution. Journal of Ecology and Rural Environment. 4, 409-415.

Curaqueo, G., Meier, S., Khan, N., Cea, M., Navia, R. 2014. Use of biochar on two volcanic soils: effects on soil properties and barley yield. Journal of Soil Science and Plant Nutrition. 14, 911-924. 
Dempster, D.N., Jones, D.L., Murphy, D.V. 2012. Clay and biochar amendments decreased inorganic but not dissolved organic nitrogen leaching in soil. Soil Research. 3, 216-221.

Dohrmann, R. 2006. Problems in CEC determination of calcareous clayey sediments using the ammonium acetate method. Journal of Plant Nutrition and Soil Science. 169(3), 330-334.

Enders, A., Hanley, K., Whitman, T., Joseph, S., Lehmann, J. 2012. Characterization of biochars to evaluate recalcitrance and agronomic performance. Bioresource Technology. 114, 644-653.

Farrell, M., Kuhn, T.K., Macdonald, L.M., Maddern, T.M., Murphy, D.V., Hall, P.A., Singh, B.P., Baumann, K., Krull, E.S., Baldock, J.A. 2013. Microbial utilization of biochar-derived carbon. Science of the Total Environment. 465, 288-297.

Graber, E.R., Harel, Y.M., Kolton, M., Cytryn, E., Silber, A., David, D.R., Tsechansky, L., Borenshtein, M., Elad, Y. 2010. Biochar impact on development and productivity of pepper and tomato grown in fertigated soilless media. Plant Soil. 337, 481-496.

Grelliera, S., Janeaub, J.L., Dang, H.N., Nguyen, T.K.C., Le, T.P.Q., Pham, T.T.T., Trang, T.T.N., Marchandh, C. 2017. Changes in soil characteristics and $\mathrm{C}$ dynamics after mangrove clearing (Vietnam). Sci. Total Environ,. 593, 654-663.

Grossman, J.M., O’Neill, B.E., Tsai, S.M., Liang, B.Q., Neves, E., Lehmann, J., Thies, J.E. 2010. Amazonian anthrosols support similar microbial communities that differ distinctly from those extant in adjacent, unmodified soils of the same mineralogy. Microbial Ecology. 60, 192-205.

Gu, M.Y., Liu, H.L., Li, Z.Q., Liu, X.W., Tang G.M., $\mathrm{Xu}$, W.L. 2014. Impact of biochar application on soil nutrients and microbial diversities in continuous cultivated cotton fields in Xinjiang. Scientia Agricultura Sinica. 20, 4128-4138.
Gul, S., Whalen, J.K., Thomas, B.W., Sachdeva, V., Deng, H.Y. 2015. Physico-chemical properties and microbial responses in biochar-amended soils: Mechanisms and future directions. Agriculture Ecosystems \& Environment. 206, 46-59.

Jin, H. 2010. Characterization of microbial life colonizing biochar and biochar-amended soils. PhD Thesis. Ithaca: Cornell University.

Khodadad, C.L.M., Zimmerman, A.R., Green, S.J., Uthandi, S., Foster, J.S. 2011. Taxa-specific changes in soil microbial community composition induced by pyrogenic carbon amendments. Soil Biology \& Biochemistry. 2, 385-392.

Milla, O.V., Rivera, E.B., Huang, W.J., Chien, C.C., Wang Y.M. 2013. Agronomic properties and characterization of rice husk and wood biochars and their effect on the growth of water spinach in a field-test. Journal of Soil Science and Plant Nutrition. 2, 251-266.

Otsuka, S., Sudiana, I., Komori, A., Isobe, K., Deguchi, S., Nishiyama, M., Shimizu, H., Senoo, K. 2008. Community structure of soil bacteria in a tropical rainforest several years after fire. Microbes and Environments. 23, 49-56.

Ouyang, L., Wang, F., Tang, J., Yu, L., Zhang, R. 2013. Effects of biochar amendment on soil aggregates and hydraulic properties. Journal of Soil Science and Plant Nutrition. 4, 991-1002.

Pandian, K., Subramaniayan, P., Gnasekaran, P., Chitraputhirapillai, S. 2016. Effect of biochar amendment on soil physical, chemical and biological properties and groundnut yield in rainfed Alfisol of semi-arid tropics. Archives of Agronomy and Soil Science. 9, 1293-1310.

Shen, Q., Hedley, M., Camps, M.A., Kirschbaum, M.U.F. 2016. Can biochar increase the bioavailability of phosphorus? Journal of Soil Science and Plant Nutrition. 2, 268-286. 
Shi, Q.H., Jiao, F., Geng, W., Li, Q.P., Shi, X.D. 2009.

An overview on research into factors hindering continuous cropping in flue-cured tobacco. Acta Tabacaria Sinica. 6, 81-84.

Sparks, D.L., Page, A.L., Loeppert, P.A., Soltanpour, P.N., Tabatabai, M.A., Johnston, C.T., Sumner, M.E. 1996. Methods of Soil Analysis Part 3: Chemical methods. Soil Science Society of America and American Society of Agronomy. Madison, WI, USA.

Spokas, K.A., Novak, J.M., Venterea, R.T. 2012. Biochar's role as an alternative $\mathrm{N}$-fertilizer: ammonia capture. Plant and Soil. 1, 35-42.

Syuhada, A.B., Shamshuddin, J., Fauziah, C.I., Rosenani, A.B., Arifin, A. 2016. Biochar as soil amendments: Impact on chemical properties and corn nutrient uptake in a Podzol. Can. J. Soil Sci. 4, 400-412.

Tarkalson, D.D., Brown, B., Kok, H., Bjorneberg, D.L. 2009. Impact of removing straw from wheat and barley fields: a literature review. Better Crops with Plant Food. 93, 17-19.

Warnock, D.D., Mummey, D.L., Mcbride, B., Major, J., Lehmann, J. 2010. Influences of nonherbaceous biochar on arbuscular mycorrhizal fungal abundances in roots and soils: results from growth-chamber and field experiments. Applied Soil Ecology. 46, 450-456.
Widowati, W., Asnah, A. 2014. Biochar can enhance potassium fertilization efficiency and economic feasibility of maize cultivation. Journal of Agricultural Science. 6, 24-32.

Zeng, X., Ma, Y., Ma, L. 2007. Utilization of straw in biomass energy in China. Renewable Sustainable Energy Rev. 5, 976-987.

Zhang, J.X., Zhang, Z.F., Shen, G.M., Wang, R., Gao, L., Kong, F.Y., Zhang, J.G. 2016. Growth performance, nutrient absorption of tobacco and soil fertility after straw biochar application. International Journal of Agriculture and Biology. 18, 983-989.

Zhang, M.K., Bayou, W.D., Tang, H.J. 2012. Effects of biochar's application on active organic carbon fractions in soil. Journal of Soil and Water Conservation. 26, 127-137.

Zhang, Y.T., He, X.H., Liang, H., Zhao, J., Zhang, Y.Q., Chen, X., Shi, X.J. 2016. Long-term tobacco plantation induces soil acidification and soil base cation loss. Environmental Science and Pollution Research. 23, 5442-5450.

Zhu, Z.Q. 2008. Current status and prospect of tobacco leaf production and research in China. Acta Tabacaria Sinica. 14, 70-73. 